\title{
MBD1 wt Allele
}

National Cancer Institute

\section{Source}

National Cancer Institute. MBD1 wt Allele. NCI Thesaurus. Code C148503.

Human MBD1 wild-type allele is located in the vicinity of $18 q 21.1$ and is approximately 15 $\mathrm{kb}$ in length. This allele, which encodes methyl-CpG-binding domain protein 1, is involved in the inhibition of gene expression. 